\title{
DUT Guide on supervision
}

Gitte Wichmann-Hansen ${ }^{1}$, Centre for Educational Development, Aarhus Universitet

\begin{abstract}
The aim of this guide is to provide tips for supervisors on how to support students as active, independent and prepared participants who drive their own projects forward. It relates to supervision of projects at bachelor-, master- and PhD level. The underlying basis of the guide is twofold: 1) supervision is an increasingly complex activity that involves a demanding set of competences; 2) a good supervisor is a flexible supervisor who can adapt to different situations, student needs and levels of the curriculum.
\end{abstract}

\section{Practical tips}

1. Align expectations early and regularly about process and product

2. Balance supervisor control and student independence

3. Monitor progress closely

4. Schedule regular planned supervision meetings

5. Ask questions to foster independence and higher order learning

6. Provide constructive feedback on text drafts

7. Use the academic community as a resource

8. Apply online tools to increase flexibility

\section{Introduction}

Supervision comprises a significant part of the teaching load in higher education as it applies to project assignments, bachelor projects, master's theses as well as doctoral research. At all levels, supervisors often value the task to a great extent. Some supervisors even describe it as 'the most rewarding aspect of academic life' (Halse, 2011), offering a unique opportunity to collaborate with students more closely than other teaching formats usually allow. Supervisors also gain pleasure by helping a student or researcher grow, and supervisors appreciate the inspiration and input they get from students, which may further their own research.

However, supervision is an increasingly complex activity, in which supervisors are having to respond to the growth and diversification of the student population (Duke \& Denicolo, 2017) as well as the increasing pressure for quality assurance and timely completion (Manathunga, 2019). Modern supervision involves a demanding set of competences. Besides guiding students' research projects, supervisors need to be good at navigating interpersonal relationships with students, managing projects and deadlines, stimulating effective writing

\footnotetext{
${ }^{1}$ Contact: gwh@au.dk
} 
processes, supporting students' professional and career development etc. (Taylor, 2019). To add to the complexity, it is well-established in the research literature that supervision is highly contextual. Some authors even claim that supervision is 'the most variable of all variables' (McAlpine \& McKinnon, 2013) because it is sensitive to a number of contextual factors such as discipline-specific features (Pyhältö et al., 2015), the project characteristics (Rooij et al., 2019), types of funding (Wichmann-Hansen \& Herrmann, 2017), the stages in the supervisory process (Benmore, 2016), students' differing needs (Harwood \& Petrić, 2020), supervisors' individual values and beliefs (Lee, 2020) and changing political agendas (Deuchar, 2008; Wichmann-Hansen et al., 2018).

To boil it down, there is no 'one size fits all' approach: A good supervisor is a flexible supervisor who can adapt to different situations. However, stressing flexibility is not equivalent to stating that there are no practical tips or strategies for good supervision. If anything, flexibility calls for a broad repertoire of strategies. Therefore, the advice listed in this guide is intended as a means of broadening supervisors' repertoire, not as a standard formula.

It is also important to stress that since the advice in this guide is phrased as generic supervision strategies that are applicable to all levels, from bachelor to $\mathrm{PhD}$, and for all types of projects, individual as well as group projects, the strategies are subject to modifications. In particular, the national qualification frameworks of higher education usually state that students' projects must demonstrate increased knowledge, originality and independence from bachelor to PhD level (Lee, 2020). Supervision strategies therefore need to be up- and downscaled to fit the relevant level of the curriculum (Sambrook et al., 2008). Tools for how to tailor supervision to different levels are provided in the tips below, where relevant.

\section{Tip 1: Align expectations early and regularly about process and product}

Students and supervisors often have differing expectations of each other (Pyhältö et al., 2015; Jansen et al., 2020), and many students find it difficult to decode what supervision entails (Barnes \& Cheng, 2018). Unspoken and contrasting expectations for the collaboration process, as well as for the academic product, can disrupt supervision (Roberts \& Seaman, 2018) and impair student success and academic persistence (Sverdlik et al., 2018). Consequently, clarifying expectations is key to building effective supervision for two reasons: It prevents insecurity about each other's roles and responsibilities, and it is a means of establishing shared standards for good research and academic writing. The latter is particularly important, because if the final assessment criteria are not communicated, made transparent, discussed, or ideally agreed upon from the beginning, students will not be able to apply and implement them adequately in their project.

\section{A Supervisor Letter}

There are a range of tools available to align expectations early in the supervision process.

At bachelor and master level, an efficient tool is to use a so-called supervisor's letter (Rienecker et al., 2019; Laustsen et al., 2012). It is a written account (2-3 pages) of the supervisor's individual practice, i.e. what students can expect from the supervisor and vice versa. As a minimum, it addresses:

- Form, e.g., when, where and how to meet? How often and who takes the initiative?

- Content, e.g., what to prepare for meetings? What kind of material and text are subject for feedback? What are the assessment criteria, product standards, genre requirements, etc.? 
- Process, e.g., planning, setting deadlines, ensuring progress and how to deal with potential delays?

The supervisor either makes the letter available online or hands it out at the first meeting and then asks for the student's response at the following meeting. The letter is not intended as a substitute for a mutual discussion about expectations, but rather as an efficient preparation for such a discussion. Helpful templates are provided in Wichmann-Hansen \& Jensen (2015, pp. 331-332) and Rienecker et al. (2019, pp. 51-55).

\section{A Memorandum of Understanding}

At the PhD level, a supervisor's letter is also applicable, especially in lab-based sciences (Masters \& Kreeger, 2017). However, a more dialogue-based and contractual tool has proven particularly successful at the PhD level, because the $\mathrm{PhD}$ process involves a more complex and long-standing relationship and students are expected to act more independently (Moxham et al., 2013). A Memorandum of Understanding is a negotiated contract between the student and the main supervisor (Anderson et al., 1998; Hockey, 1996) and ideally also the cosupervisor(s) (Robertson, 2019). It features a set of guiding questions for starting a structured discussion about goals, ambitions and how to collaborate, including the student's responsibility and individual needs, the supervisors' different roles in the team, integration into the wider research environment and, if necessary, coauthorships. All participants read the questions beforehand and prepare answers. Based on a joint discussion of the questions, agreements are noted in a shared document. Helpful templates are provided in Taylor et al. (2018, p. 78) and are available for download at Postgradenvironments.com.

\section{Meta-communication: a tool for regular alignment of expectations}

Setting expectations isn't a one-off event, though. Relationships and research projects develop over the course of time and thus, expectations need to be revisited. An efficient tool for aligning expectations regularly is to meta-communicate, i.e. to communicate about the communication (Baltzersen, 2013; Handal \& Lauvås, 2006). It is a means of explicating what is going on in supervision meetings, the intentions behind what is said, and how the participants experience it. The tool can be useful in preventing conflicts and addressing misunderstandings. A prime example of a conflictual situation is when students want clear-cut answers, while the supervisor is reluctant to simply spoon-feed students. In that case, supervisors could meta-communicate to increase students' willingness to be more active and independent, e.g. by saying:

'It's my impression that you expect me to give you some advice. I will give you some along the way, but first I need to know more about how you perceive the problem and how you have tried to solve it yourself. Your question is so important that it deserves more than a hasty answer. So, let me ask you some counter-questions to help you clarify your arguments.'

\section{Tip 2: Balance supervision control and student independence}

Good supervision requires a careful balance between providing advice and guidance and allowing the student to experience their own learning journey - including making mistakes. There is not a clear-cut answer to how directive and controlling supervisors should be (Bastalich, 2017), but an overall navigating principle is to use a staged approach from directive towards less directive supervision (Barnes \& Cheng, 2018; Benmore, 2016; Anderson et al., 2006; Todd et al., 2006). Students will often need substantial guidance at the beginning of a 
project and when starting to produce texts, because they have not yet fully internalised standards for scientific projects and genre criteria. Consequently, supervisors should invest time in ensuring a well-defined focus and a clear structure for the thesis, an academically appropriate research design and a realistic timetable. They may provide concrete genre templates, demonstrate how to search for literature, suggest models, theories and methods, and instruct how to plan and manage time. Over the course of the project, it is, however, reasonable to expect greater student independence and to push students to take full ownership of their projects. Gurr (2001) provides a useful illustration of the staged approach. His model is also intended as a concrete tool for explicitly communicating and reflecting with students about their perceived and experienced levels of independence. In addition to Gurr's tool, which is mainly aimed at the PhD level, supervisors can support student independence in many ways, of which the following are merely examples (Rienecker et al., 2019):

- Explicate how independence is assessed in the final product according to the learning outcomes in the study programme, the ministerial order, the scientific discipline or the local departmental culture.

- Share examples of good theses that demonstrate independence in terms of higher order-thinking skills, e.g. how students have made a profound analysis or reflected critically on data and literature

- Ask students to identify independence in their own drafts.

- Inform students how independence is construed and administered in the supervision process, e.g., write it in the supervisor letter: 'To me, independence means that students should take responsibility for ....'

\section{Tip 3: Closely monitor progress}

The increasing pressure for timely completion of both master's and PhD thesis calls for a more structured supervision process in terms of early planning and closely monitoring of students' projects (Marnewick, 2020). A twofold approach to support progress is recommended (Rienecker et al., 2019):

\section{Try to prevent delay}

- Agree on milestones early: Recommend students to create a visual timeline and to plot in the end-date and milestones. Discuss it and adjust if necessary.

- Incite students to start writing early (from day one!) and ask for text drafts continuously as a basis for supervision meetings. Drafts may be very sketchy and include outlines, data displays, literature searches etc.

- Suggest that students estimate the number of pages and time spent for each section in their text regardless of whether it is the total thesis or a single article. Make it subject to supervision.

- Advise students not to save up supervision for later. Supervision in the early phase is irreplaceable, because here essential decisions about the research design are made.

\section{React promptly in case of delay}

If students postpone deadlines or stay away from meetings:

- Renew contact by mail or phone, e.g. I haven't heard from you for a while. How are things going?

- Identify reasons for delay: Is it cognitive, personal or social? Be curious when asking.

- Ask how the student prefers to solve the situation (and how you can help) 
- Decide on a weekly or monthly contract: What shall the student(s) and, if necessary, the supervisor do from now on?

- Support a low threshold for writing, for a while: Incite production instead of a high-quality product. For instance, ask for five sketchy research questions instead of one polished.

- Look at the text drafts. Do not settle for talking.

- Give a clear assessment of the preliminary research design in the project: Is it doable or not? Do not waffle.

\section{Tip 4: Schedule regular prepared meetings}

Supervisors should insist on scheduling regular and prepared meetings in addition to ad-hoc and informal contact (Sverdlik et al., 2018). The idea is to allow for thorough discussions and for students to take on an active and responsible role in driving their own projects forward. Preparation on both sides also ensures efficient meetings:

- Request drafts well in advance of meetings, e.g. two days beforehand

- Ask for a meeting agenda. Make it a habit for students to always answer minimum 4 items:

1. What have you been working on since we met last time?

2. Have you encountered any difficulties?

3. What would you like to discuss at our upcoming meeting?

4. How well are you keeping to the time plan?

- Ask the student to send a short summary of the meeting.

\section{Tip 5: Ask questions to foster independence and higher order learning}

A common pitfall for supervisors is to lecture and give too many authoritative instructions, either because time is short or because they are eager to help and give advice. By entering into a real dialogue (Dysthe, 2006; Magnusson, 2021), supervisors can:

- encourage student independence

- support higher order learning and critical thinking skills

- reduce the inherent asymmetrical power relationship.

To practice dialogue-based supervision, it can be helpful to structure the conversation. A relevant tool for this is The Questioning Whee/(Wichmann-Hansen \& Jensen, 2015: 339). It illustrates how a supervision dialogue can be structured around four phases with matching questions. The basic principle is for supervisors to carefully familiarise themselves with the issues that students are preoccupied with before supervisors contribute their own views and advice. See Figure 1. 


\section{The Questioning Wheel}

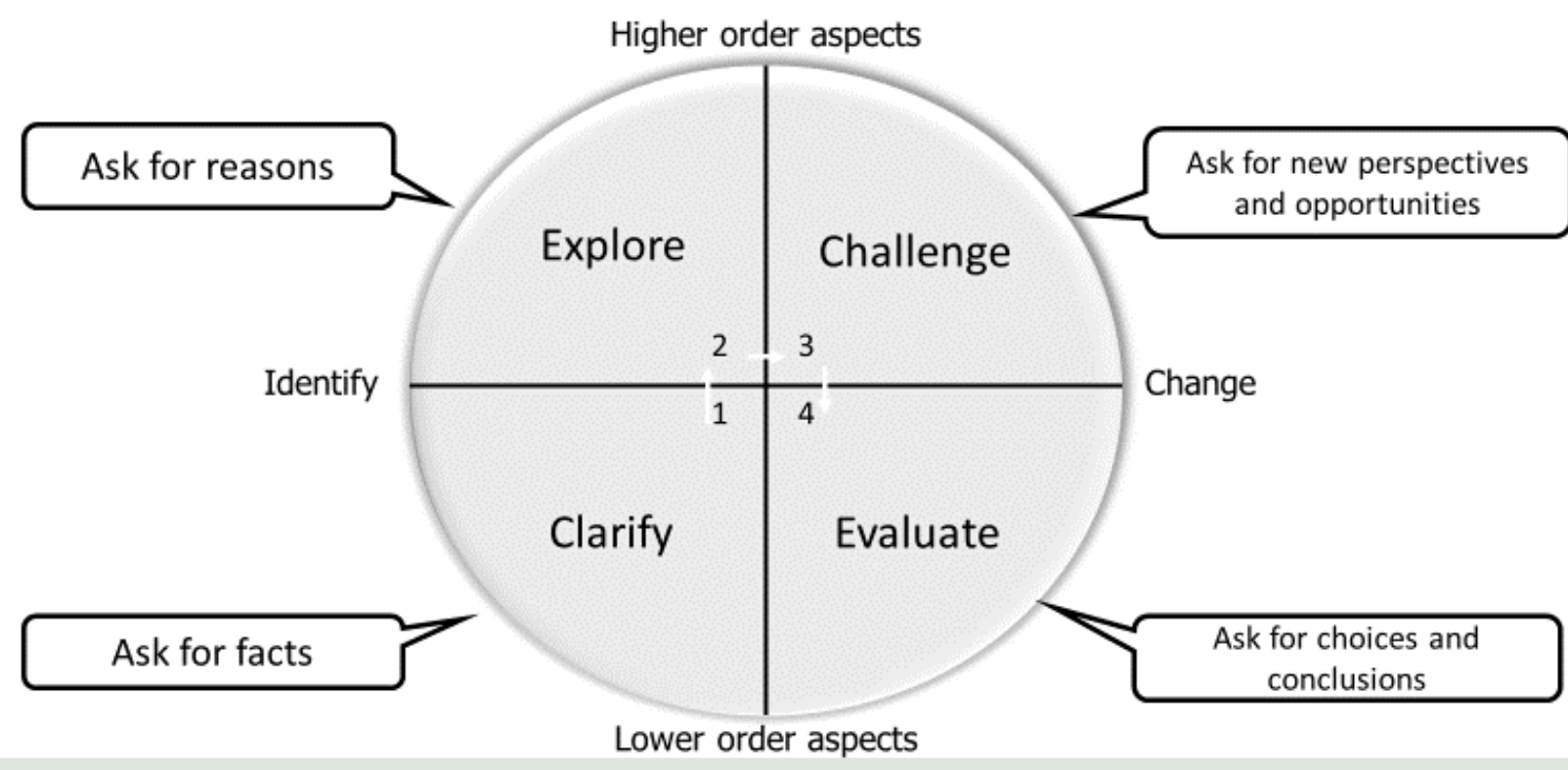

Figure 1: The Questioning Wheel

1. In the first phase, supervisors listen to the ideas, questions, or problems that the student presents. Clarifying questions are particularly useful at this stage to identify students' needs and expectations and to allow students to elaborate on their ideas early in the conversation, e.g. What literature have you found? How did you search for it?

2. In the second phase, the supervisor is more focused on activating the thinking and argumentation that drive the student's decisions and actions. By asking exploring questions, supervisors can illuminate the reasons behind students' choices, e.g. What are your arguments for...? Why did you choose to....?

3. Here, the supervisor becomes more critical. By asking challenging questions, the supervisor may inspire students to view the situation from new angles and consider alternative courses of action, e.g. What would happen if...? What other perspectives could you imagine?

4. The last phase is mainly about drawing conclusions from the meeting. By asking evaluating questions supervisors can help students summarise the main points and how to proceed after the meeting, e.g. To sum up, what are the main conclusions? What is the plan until next meeting?

To implement the model successfully, supervisors should 1) meta-communicate that they expect students to assume an active role in the dialogue, and 2) remember that a dialogue does not preclude advice. Supervisors need to be present as academic authorities by correcting, arguing, using clear scientific criteria and advising when needed. 


\section{Tip 6: Provide constructive feedback on text drafts}

An essential part of supervision is to read students' drafts and to diagnose whether their material meets the requirements for academic texts (Rienecker et al, 2019).

The first step is therefore to help students know about and apply genre criteria (Jensen, 2019). At the bachelor and master's level, supervisors can direct students to instructive handbooks on academic writing, e.g., Rienecker and Jørgensen (2017), which, among other things, includes a visual model (Pentagon) to help students formulate their research design, including clear research questions. At PhD level, supervisors can share genre templates for articles, e.g. Lichtfouse (2013) and Lindsay (2011). Using templates is also a way of making sure that students keep an eye on 'the big picture' and write more efficiently. For instance, supervisors can encourage students to put in bullet points or summaries in templates (e.g. what do you want to say here?) before asking for full drafts.

The second step is to provide formative feedback that is aligned with the assessment criteria. First and foremost, supervisors should substantiate their feedback by referring to the formally established genre criteria and quality standards that are specified in course descriptions or journal guidelines, etc. (Hattie, 2007) Furthermore, research recommends that supervisors position students as active participants in the feedback process (Winstone et al., 2021) by applying key principles (Ajjawi et al., 2021; O'Donovan et al., 2021):

- Ask students to append cover letters when sharing drafts. The idea is to tailor feedback to students' needs. Make it a habit for students to answer some questions in a cover letter, e.g.:

1. What kind of text have you sent? (Where does it fit in the overall thesis)?

2. How drafty or polished is it?

3. What challenges have you faced when writing the text?

4. What would you like feedback on?

- Invite for a dialogue. Feedback calls for a face-to-face conversation that allows for clarification and elaboration on comments. Written feedback without dialogue is seldom sufficient.

- Prioritise. Provide a few well-thought-out and explained comments on the overall text before focusing on details, e.g. 'My three most important comments are...'

- Be specific. Refer to concrete and local text passages, e.g. 'Here on p. 9 you strongly support your claim when you write...'.

- Be instructive. Provide concrete suggestions for how to improve the text.

- Evaluate the feedback. Show an interest in how students perceive the feedback and how they will apply it.

\section{Tip 7: Use the academic community as a resource}

Whilst it is strongly established that supervisors play a significant role for students' timely completion, wellbeing, satisfaction, and productivity (Sverdlik et al., 2018), recent studies suggest that there are benefits in moving beyond the traditional student-supervisor relationship (McAlpine et al., 2020). Engaging socially and intellectually with peers and faculty can reduce students' stress and loneliness and increase motivation, retention, and feelings of independence. At PhD level, there is a variety of ways to engage students in the wider research community, including team-based learning, cohort supervision, presenting at research group meetings, peer assessment, journal clubs, writing groups etc. (Woodhouse \& Wood, 2020). At the bachelor and master level, collective supervision with peer-feedback has proven useful as a means to increase student engagement, 
progress and completion rates (Nordentoft et al., 2013; Lélis, 2020; Agne \& Mörkenstam, 2018; Akister et al., 2009; Dysthe et al., 2006) and to increase supervisor time efficiency (Baker, 2014).

However, implementing peer-feedback and cohort learning formats require careful planning and facilitation (Müllen, 2019) and training of students' so-called feedback literacy (Winstone \& Carless, 2019). For a comprehensive guide on how to practice collective supervision with peer-feedback, see Nordentoft et al. (2019).

\section{Tip 8: Apply online tools to enhance flexibility}

Online tolls are becoming more and more natural in supervision due to increased international mobility and distance education as well as the recent global corona pandemic (Nash, 2021). Studies suggest that online tools for meeting and communication can enhance flexibility, collaboration and a sense of belonging to the community (Kumar et al, 2020). Research also shows promising results of applying screencast and audio software when providing text feedback in terms of flexibility, efficiency and quality (Mahoney et al., 2018). However, a critical drawback of online supervision meetings is the lack of a spatial dimension (Altekruse \& Brew, 2000), which makes it difficult to sense and decode the other's body language, mimic, tone and voice (Nielsen $\&$ Wichmann-Hansen, 2019). Building friendly, trustful interpersonal relationships is particularly important in supervision (Wisker, 2012) and therefore, online supervision makes great demands on supervisors' social competences (Kumar \& Johnson, 2019). For specific advice on how to navigate online supervision meetings, see Wichmann-Hansen \& Nielsen (2019).

\section{Conclusion}

The best trait of any supervisor is probably adaptability and being able to draw on all the strategies listed above, depending on the student and the stage of the supervisory relationship. As with any other human relationships, supervision is a two-way process. Both student and supervisors should be sensitive to each other's needs and manners of working and should communicate these issues with each other when needed.

\section{References}

Agné, H., \& Mörkenstam, U. (2018). Should first-year doctoral students be supervised collectively or individually? Effects on thesis completion and time to completion. Higher Education Research \& Development, 37(4), 669-682.

Ajjawi, R., Kent, F., Broadbent, J., Tai, J. H.-M., Bearman, M., \& Boud, D. (2021). Feedback that works: a realist review of feedback interventions for written tasks. Studies in Higher Education, DOI:

10.1080/03075079.2021.1894115

Akister, J., Williams, I., \& Maynard, A. (2009). Using group supervision for undergraduate dissertations: a preliminary enquiry into the student experience. Practice and Evidence of the Scholarship of Teaching and Learning in Higher Education 4(2) 77-94

Altekruse, M. K., \& Brew, L. (2000). Using the web for distance learning. In J. W. Bloom, \& G. R. Walz (Eds.), Cybercounseling and cyberlearning: Strategies and resources for the millennium (pp. 129-141). Alexandria: American Counseling Association. 
Anderson, G., Boud, D., \& Sampson, J. (1998). Qualities of Learning Contracts. In: J. Stephenson J., \& M. Yorke (Eds.), Capability and Quality in Higher Education (pp. 162-173). Kogan Page.

Anderson, C., Day, K. \& McLaughlin, P. (2006). Mastering the Dissertation: Lecturers' Representations of the Purposes and Processes of Master's Level Dissertation Supervision. Studies in Higher Education, 31(2), 149168.

Baker, M.J., Cluett, E., Ireland, L., Reading, S., Rourke, S. (2014). Supervising undergraduate research: a collective approach utilising groupwork and peer support. Nurse Education Today 34(4), 637-642.

Baltzersen, R.K. (2013). The Importance of Metacommunication in Supervision in Higher Education. International Journal of Higher Education, 2(2), 128-40

Barnes, G.P., \& Cheng, M. (2019). Working independently on the dissertation proposal: experiences of international master's students. Journal of Further and Higher Education, 43(8), 1120-1132

Bastalich, W. (2017). Content and context in knowledge production: a critical review of doctoral supervision literature. Studies in Higher Education, 42(7), 1145-1157.

Benmore, A. (2016). Boundary management in doctoral supervision: how supervisors negotiate roles and role transitions throughout the supervisory journey. Studies in Higher Education, 41(7), 1251-1264

Deuchar, R. (2008). Facilitator, director or critical friend? Contradiction and congruence in doctoral supervision styles. Teaching in Higher Education, 13(4), 489-500.

O'Donovan, B.M., den Outer, B., Price, M., \& Lloyd, A. (2021). What makes good feedback good? Studies in Higher Education, 46(2), 318-329.

Duke, D.C., \& Denicolo, P.M. (2017). What supervisors and universities can do to enhance doctoral student experience (and how they can help themselves). FEMS Microbiol Lett., May 1;364(9). DOI: https://doi.org/10.1093/femsle/fnx090

Dysthe, O., Samara, A., \& Westrheim, K. (2006). Multivoiced supervision of Master's students: a case study of alternative supervision practices in higher education. Studies in Higher education, 31(3), 299-318.

Dysthe, O. (2006). Rettleiaren som lærer, partnar eller meister? In O. Dysthe, \& A. Samara (Eds.), Forskningsveiledning på master- og doktorgradsnivå (pp. 228-248). Abstrakt Forlag.

Gurr, G.M. (2001). Negotiating the "Rackety Bridge" - a Dynamic Model for Aligning Supervisory Style with Research Student Development. Higher Education Research \& Development, 20(1), 81-92.

Halse, C. (2011). 'Becoming a supervisor': The impact of doctoral supervision on supervisors' learning. Studies in Higher Education, 36(5), 557-570.

Handal, G., \& Lauvås, P. (2006). Forskningsveilederen. Cappelen Akademisk Forlag.

Harwood, N., \& Petrić, B. (2020). Adaptive master's dissertation supervision: a longitudinal case study. Teaching in Higher Education, 25(1), 68-83. 
Hattie, J., \& Timperley, H. (2007). The Power of Feedback. Review of Educational Research, 77(1), 81-112.

Hockey, J. (1996). A contractual solution to problems in the supervision of PhD degrees in the UK. Studies in Higher Education, (21)3, 359-371.

Janssen, S., Vuuren, M.v \& de Jong, M.D.T. (2020). Sensemaking in supervisor-doctoral student relationships: revealing schemas on the fulfillment of basic psychological needs. Studies in Higher Education, DOI: 10.1080/03075079.2020.1804850

Jensen, T. W. (2019). DUT Guide om akademisk skrivning. Dansk Universitetspædagogisk Tidsskrift, 14(26), $115-124$

Kumar, S., \& Johnson, M. (2019). Online mentoring of dissertations: the role of structure and support. Studies in Higher Education 33(1), 59-71.

Kumar, S., Kumar, V., \& Taylor, S. (2020). A Guide to Online Supervision. UK Council for Graduate Education. Retrieved from http://www.ukcge.ac.uk/media/download.aspx?MediaId=2268

Laustsen, S., Wichmann-Hansen, G., Aagaard, H., Bahrami, G., \& Dreyer, P. (2012). Brugen af vejlederbrev til universitetsstuderende - en diskussion af dets betydning i vejledningsprocessen. Dansk Universitetspædagogisk Tidsskrift, 7(12), 46-57.

Lee, A. (2020). Successful Research Supervision. Advising students doing research. Routledge.

Lélis, C. (2020). It's milestone, Not limescale! Milestoned group supervision as an approach to descale postgraduate projects. New Vistas 6(1), 26-31

Lichtfouse, R. (2013). Scientific Writing for Impact Factor Journals. Nova Science Publishers, Inc.

Lindsay, D (2011). Scientific writing = Thinking in Words. CSIRO Publishing. ISBN: 9780643101579

Lovitts, B. (2008). The Transition to Independent Research: Who Makes It, Who Doesn't, and Why. The Journal of Higher Education, 79(3), 296-325.

Magnusson, J. (2021). Handledarens frågor: Att möjliggöra självständighet i ett handledningssamtal. Högre utbildning, 11(1), 56-75.

Mahoney, P., Macfarlane, S., \& Ajjawi, R. (2018). A qualitative synthesis of video feedback in higher education. Teaching in Higher Education, 24(2), 157-179

Manathunga, C. (2019). 'Timescapes' in doctoral education: the politics of temporal equity in higher education. Higher Education Research \& Development, 38(6), 1227-1239.

Marnewick, A.L. (2020). A supervision approach to facilitate learning during the master's research journey. Teaching in Higher Education, DOI: 10.1080/13562517.2020.1811223

Masters K.S., \& Kreeger, P.K. (2017). Ten simple rules for developing a mentor-mentee expectations document. PLoS Comput Biol 13(9): e1005709. https://doi.org/10.1371/journal.pcbi.1005709 
McAlpine, L., Castello, M., \& Pyhaltö, K. (2020). What influences PhD graduate trajectories during the degree: a research-based policy agenda. Higher Education 80, 1011-1043

McAlpine, L., \& McKinnon, M. (2013). Supervision - the most variable of variables: Student perspectives. Studies in Continuing Education, 35, 265-280.

Moxham, L., Dwyer, T., \& Reid-Searl, K. (2013). Articulating expectations for PhD candidature upon commencement: ensuring supervisor/student 'best fit'. Journal of Higher Education Policy and Management, 35(4), 345-354.

Müllen, R. von. (2019). DUT Guide: Peer-Feedback. Dansk Universitetspædagogisk Tidsskrift, 14(27), 188-196.

Nash, C. (2021). Improving Mentorship and Supervision during COVID-19 to Reduce Graduate Student Anxiety and Depression Aided by an Online Commercial Platform Narrative Research Group. Challenges, 12, 11. https://doi.org/10.3390/challe12010011

Nielsen, T.A., \& Wichmann-Hansen, G. (2019). Supervision of students' projects: How to support and increase flexibility and efficiency by use of web 2.0 technologies? In J. Theo Bastiaens (Ed.), Proceedings of EdMedia + Innovate Learning (pp. 1757-1761). https://www.learntechlib.org/primary/p/210200/.

Nordentoft, H. M., Thomsen, R., \& Wichmann-Hansen, G. (2013). Collective academic supervision: a model for participation and learning in higher education. Higher Education, 65(5), 581-593.

Nordentoft, H.M., Hvass, H., \& Mariager-Anderson, K. (2019). Kollektiv Akademisk Vejledning. Fra forskning til praksis. Aarhus Universitetsforlag.

Pyhältö, K., Vekkaila, J., \& Keskinen, J. (2015). Fit matters in the supervisory relationship: doctoral students and supervisors' perceptions about the supervisory activities. Innovations in Education and Teaching International, 52(1), 4-16.

Rienecker, L., \& Jørgensen, P.S. (2017) The Good Paper. A handbook for writing papers in higher education (2nd ed.). Frederiksberg, Samfundslitteratur.

Rienecker, L., Wichmann-Hansen, G., \& Jørgensen, P.S. (2019). God vejledning af specialer, bacheloropgaver og projekter. Frederiksberg, Samfundslitteratur.

Robert, L.D., \& Seaman, K. (2018). Good Undergraduate Dissertation Supervision: Perspectives of Supervisors and Dissertation Coordinators. International Journal for Academic Development, 23 (1), 28-40.

Robertson, M. J. (2019). Power and Doctoral Supervision Teams: Developing Team Building Skills in Collaborative Doctoral Research. Routledge.

Rooij, E. Van, Fokkens-Bruinsma, M., \& Jansen, E. (2019). Factors that influence PhD candidates' success: the importance of PhD project characteristics. Studies in Continuing Education, DOI:

10.1080/0158037X.2019.1652158

Sambrook, s., Stewart, J., \& Roberts, C. (2008). Doctoral supervision ... a view from above, below and the 
middle! Journal of Further and Higher Education, 32(1), 71-84

Sverdlik, A., Hall, N., McAlpine, L., \& Hubbard, K. (2018). The PhD experience: a review of the factors influencing doctoral students' completion, achievement, and well-being. International Journal of Doctoral Studies, 13, 361388.

Todd, M.J., Smith, K., \& Bannister, P. (2006). Supervising a social science undergraduate dissertation: staff experiences and perceptions. Teaching in Higher Education, 11((2), 161-173.

Taylor, S., Kiley, M., \& Humphrey, R. (2018) Handbook for Doctoral Supervisors. 2nd Edition. Routledge, 2017.

Taylor, S. (2019). Good supervisory practice framework. UK Council for Graduate Education. Retrieved 27.05.2021 from https://supervision.ukcge.ac.uk/good-supervisory-practice-framework/

Wichmann-Hansen, G., \& Herrmann, K.J. (2017). Does external funding push doctoral supervisors to be more directive? A large-scale Danish study. Higher Education, 74(2), 357-376.

Wichmann-Hansen, G., Herrmann, K.J., Bager-Elsborg, A., \& Andersen, P. (2018). Hvad er konsekvensen af Fremdriftsreformen for specialevejledning? [Paper presentation]. DUN Konferencen, Denmark, https://dunnet.dk/media/489845/pa13-hvad-er-konsekvensen-af-fremdriftsreformen-for-specialevejledning.pdf

Wichmann-Hansen, G., \& Jensen, T.W. (2015). Supervision: Process management and communication. In L. Rienecker, P.S. Jørgensen, J. Dolin, G.H. Ingerslev (Eds.), University Teaching and Learning (pp. 327-492). Forlaget Samfundslitteratur

Wichmann-Hansen, G., \& Nielsen, T.A. (2019). Online vejledning. In L. Rienecker, G. Wichmann-Hansen, \& P.S. Jørgensen, God vejledning af specialer, bacheloropgaver og projekter (pp. 211-219). Forlaget Samfundslitteratur.

Winstone, N. E., \& Carless, D. (2019). Designing Effective Feedback Processes in Higher Education: A LearningFocused Approach. Routledge.

Winstone, N.E., Ajjawi, R., Dirkx, K., \& Boud, D. (2021). Measuring what matters: the positioning of students in feedback processes within national student satisfaction surveys. Studies in Higher Education, DOI: 10.1080/03075079.2021.1916909.

Wisker, G. (2012) The Good Supervisor. Supervising Postgraduate and Undergraduate Research for Doctoral Theses and Dissertations (2nd ed.). Palgrave Macmillan

Woodhouse, J., \& Wood, P. (2020). Creating dialogic spaces: developing doctoral students' critical writing skills through peer assessment and review. Studies in Higher Education, DOI: 10.1080/03075079.2020.1779686 


\section{Betingelser for brug af denne artikel}

Denne artikel er omfattet af ophavsretsloven, og der må citeres fra den.

Følgende betingelser skal dog være opfyldt:

- Citatet skal være i overensstemmelse med "god skik"

- Der må kun citeres „i det omfang, som betinges af formålet"

- Ophavsmanden til teksten skal krediteres, og kilden skal angives ift. ovenstående bibliografiske oplysninger

\section{(c) Copyright}

DUT og artiklens forfatter
Udgivet af

Dansk Universitetspædagogisk Netværk 